\title{
Implementation of GASING Stock Gamification to Increase Financial Literacy for High School Students
}

\author{
Florentina Kurniasari \\ Universitas Multimedia Nusantara \\ florentina@umn.ac.id
}

\begin{abstract}
Financial inclusion played an essential role in increasing the nation's welfare. Therefore, it is crucial to increase financial literacy since the literacy index in Indonesia is still 38,03\%. Stock market investment had the lowest contribution toward the level of literacy index. The advancement of ICT and the penetration of internet users support the spreading of financial information among the young generation. Due to its low literacy rate, Indonesians are still vulnerable to false financial information, leading to investment fraud. Gamification is chosen as an alternative method in taking advantage of interactive game development that can easily download via smartphone. The gamification system design, which is named GASING, gives the younger generation adequate information related to secure financial investment. The target game user of GASING is high-school students. The feature of the GASING that offer attractive UI/UX design was expected to increase the knowledge of high-school students in learning stock investment. The usage of GASING gamification was also expected to increase more young generation participation in the Indonesian capital market while simultaneously increasing their knowledge, skills, and confidence in the stock market.
\end{abstract}

Keywords: Financial Literacy, Stock Gamification, GASING, High-School Students

\section{How to Cite:}

Kurniasari, F., (2021). Implementation of GASING stock gamification to increase financial literacy for High School Students. International Journal of Finance Research, 2(4). 274 - 285. DOI: https://doi.org/10.47747/ijfr.v2i4.507

\section{Introduction}

According to Financial Services Authority (Otoritas Jasa Keuangan=OJK), Financial Inclusion Index is defined as the availability of access to various financial institutions, products, and services by the needs and capabilities of the community to improve the welfare of the community. Finance literacy is one of the dimensions of financial inclusion. Financial Literacy Index refers to knowledge, skills, and beliefs that influence attitudes and behaviour to improve the quality of decision-making and financial management to achieve prosperity (Natalia et al., 2020).

According to Financial Inclusion Index data, financial institutions, services, and products are now more accessible to the public than in 2016. The figure stood at $67.8 \%$ in 2016 and has improved to $76.19 \%$ in 2019. Despite this, the Financial Literacy Index results for 2019 show

Published by: 
that knowledge, skills, and beliefs are still far too low at $38.03 \%$. We can conclude that even though $76.19 \%$ of institutions, services, and products are available to the public, the knowledge and skills associated with them are lacking.

The advancement of ICT technology has played an important role in supporting the government program to increase Indonesian financial literacy. Technology has become an integral part of today's society, including in the financial and investment sectors. It has become easier to locate information and to gain access to it through different forms of investment. However, there are disadvantages as well. Much false information and investment fraud circulate through the internet. The situation is made worse by the pandemic, while on the economic front, people are more demanding. In the absence of knowledge and skills, information tends to be accepted without scrutiny, leading to abusive behaviour by some irresponsible parties. To induce the target to invest in the no-risk type, parties use propaganda to manipulate their target's feelings. Propaganda manipulates readers' feelings by using both positive and negative emotions to trigger a sense of calmness to confuse the target and enforce a feeling of trueness (Ghanem \& Rosso, 2020).

According to Satgas Waspada Investasi (SWI), Indonesians have been swindled out of 117.4 trillion Indonesian Rupiah over the last decade due to fraudulent investment practices. The highest loss caused by fraudulent investments occurred in 2011, absorbing up to 68.62 Indonesian Rupiah trillion funds. In 2019, the perpetrators managed to get their hands on 4 trillion Indonesian Rupiah. It has 442 illegal investments, 1.493 illegal financial technology (fintech) loans, and 68 illegal pawns.

Meanwhile, the number of Indonesian investors keeps on increasing year after year. As of September 2021, there are 6,4 million investors compared to 3.8 million investors in 2020, which shows a significant increase of $65,73 \%$. KSEI statistics show that $59.23 \%$ of investors are under the age of 30, indicating that Generation $Z$ investors represent the majority of investors, representing most of them being high school students. Generation $\mathrm{Z}$ is classified at the age range of 17 years old up to 29 years old. Generation $Z$ intended to focus on short-term investments that would bring higher returns than long-term financial instruments (Yanto et al., 2020). Generation $\mathrm{Z}$ tends to have a sense of flow from social networks where everything changes swiftly. They also tend to perceive only brief, visual information. In the multitasking mode, they feel very confident but focusing on finishing a task requires tremendous effort (Matraeva et al., 2019). This may lead to a short-term - trading type of investment with no in-depth research/analysis, which may also give an advantage to the fraud doers.

To increase investment in Indonesia, the Indonesian government has launched a movement called 'Yuk Nabung Saham' since November 15, 2015. With this movement, the society aims to become as knowledgeable about the capital market as soon as possible, which is at 17 years of age (Ramadhani, 2021). In conjunction with financial literacy support from the ministry of education and culture, which supports education about financial literacy since early stages. The movement has resulted in investors growing to 4.5 million capital market investors from 0.4 million at the end of 2015 (KSEI,2021).

The capital market itself has a bad reputation in society, where investment in the capital market is viewed as a gamble. Furthermore, investment fraud has increased since the pandemic in Indonesia, where it offered high returns without a risk that attracts investors. Through OJK (2021), the government has encouraged investors to learn about the legality of an investment

Published by: 
before investing in an instrument product. Additionally, OJK uses digital platforms to continue educating investors about secure investment in the stock market. Digital platforms, including gamification, was chosen since it attracts the younger generation.

Alshowaier (2018) defines gamification as a method that turns non-game context into an application of video games to increase engagement and motivation in learning. It is an innovation considering the game culture spreading all around the world. In correlation with stock, gamification turns stock market education into a form of the game. It stimulates and educates people about the stock market in the interactive way of a game, so more people are learning about the capital market.

The usage of the stock gamification was expected to increase the financial literacy related to stock market investment among high school students. This interactive Android-based game application offered simplicity and convenience since it is accessible anywhere through the smartphone. The game was educational since it gave trading simulation that could be played interactively and brought an enjoyable experience. Once the high-school students are familiar with the stock market concept, they will be interested in learning more and finally will become stock market investors.

\section{Literature Review}

\subsection{Financial Literacy and Financial Knowledge}

Financial knowledge is defined as the ability to calculate financial information, such as inflation, interest rates, and risk and returns (Kadoya \& Khan, 2020). It progresses into the ability to control one's financial conduct and mindset. A financially educated person should understand basic financial concepts such as lending and borrowing, insurance, investments, and savings and have a favourable attitude regarding personal finances (Nano, 2015). People are discovering that financial literacy is a necessary skill. Financial knowledge is one of few important determinants to examine financial literacy (Rai et al., 2019).

\subsection{Stock Investment}

The aim of individual investors in choosing stocks is projected into investor behaviour in stock investment decision-making. Individual investors' objectives are reflected in stock return estimates based on various analyses (Pahlevi \& Oktaviani, 2018). Fundamental and technical analysis are two methodologies often used to assess and predict financial market activity. The first method examines the economic factors that may impact market movements and is best suited for longer-term forecasting. On the other hand, the technical analysis considers that the price already incorporates the fundamentals that influence it (Cavalcante et al., 2016).

\subsection{Gamification}

Gamification is a method that turns non-game context into an application of video games (Alshowaier 2018). Therefore, it can motivate and engage a person more in non-game contexts like stock market education. Gamification itself impacts positively on social present and sense (Antonaci et al., 2019), even though the research only shows a partially correlated relationship between social present and sense and engagement. A study by van Roy and Zaman (2018) also found that those game elements affect the motivation factor in gamification, although the motivational impact depends on the person.

Published by:

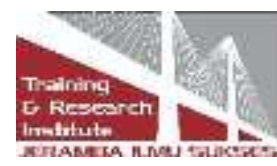




\section{Research Method: Gamification System Design (GASING)}

GASING is a simulation learning game intended for beginners, exceptionally high school students. GASING. GASING was developed to support the IDX program to educate high-school students and introduce the stock market investment. The game's idea is to replicate stock trading in an interactive, educational, and entertaining way. The game's goal is to reassure players that stock trading/investment is a safe investment instrument as long as an investor has a piece of adequate financial knowledge before making a financial investment. Players will also understand stock terminology and analytical techniques, allowing them to weigh the risk and return of stock investment. GASING system development is built using the Unity program. This game itself mainly consists of three levels.

\section{- GASING Main Menu}

The main menu of this game displays the GASING logo and also the button to start game.



Figure 1: GASING Main Menu

\section{- Introduction Menu}

After clicking the start menu button, it will continue to the introduction menu, where it is explained about the mechanism of the game and in-game goals. Furthermore, the user can decide their investor profile, including name, age, job, and avatar. 


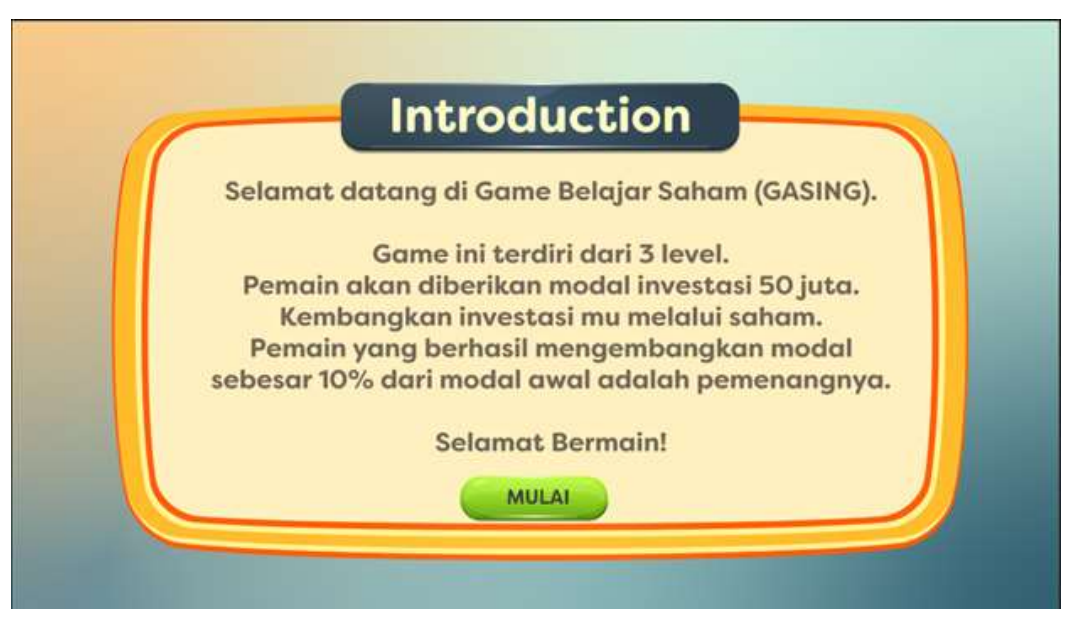

Figure 2: GASING Introduction Message

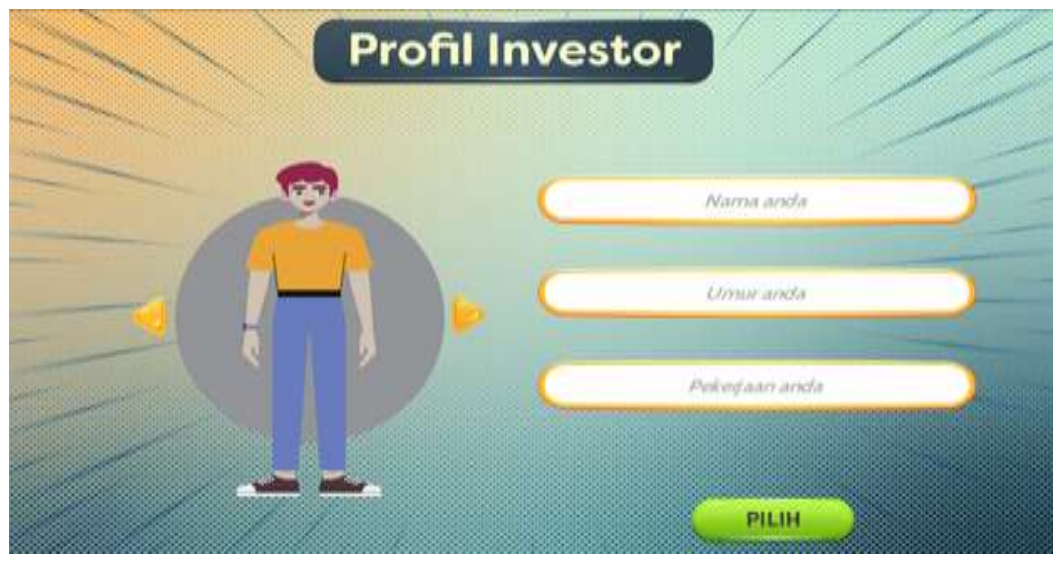

Figure 3: GASING Investor's Profile

\section{- GASING Level}

\section{Level 1}

In the first level, it will introduce related capital market institutions where the player will enter 3 buildings that will explain the institution's job in the capital market. After that, a quiz will reward money to buy stock in the second level.

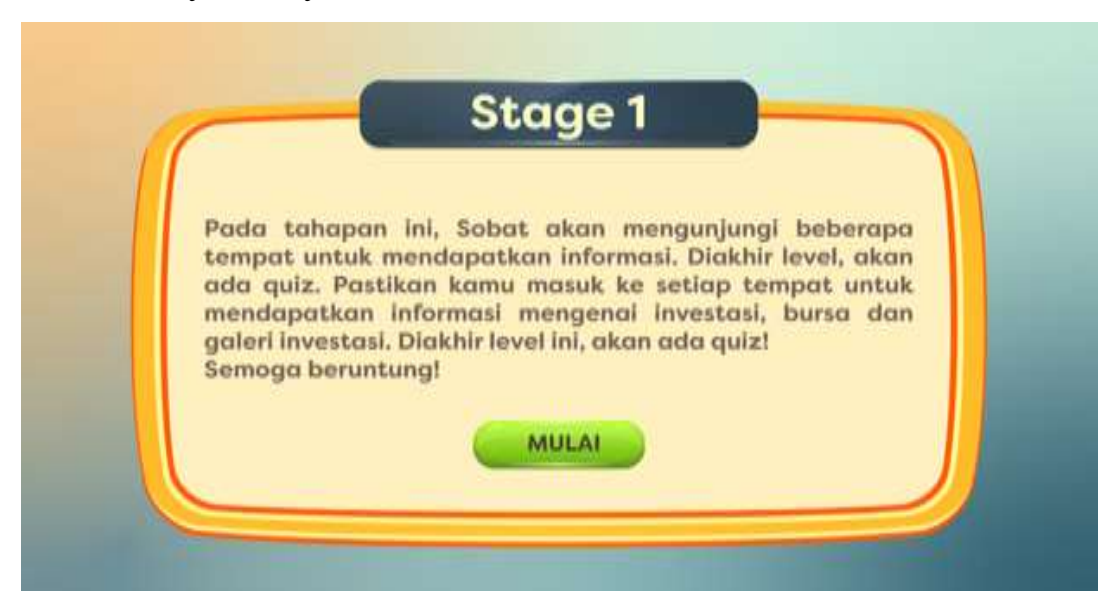

Published by:

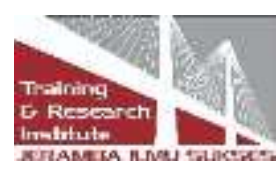


Figure 4: GASING Stage 1 Message

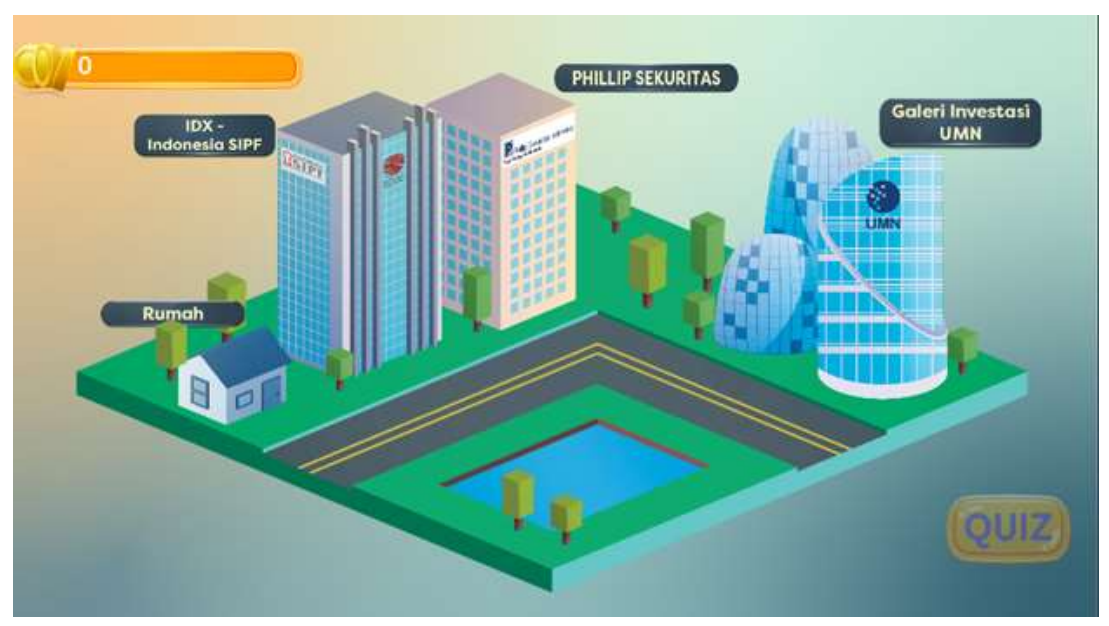

Figure 5: GASING Stage 1

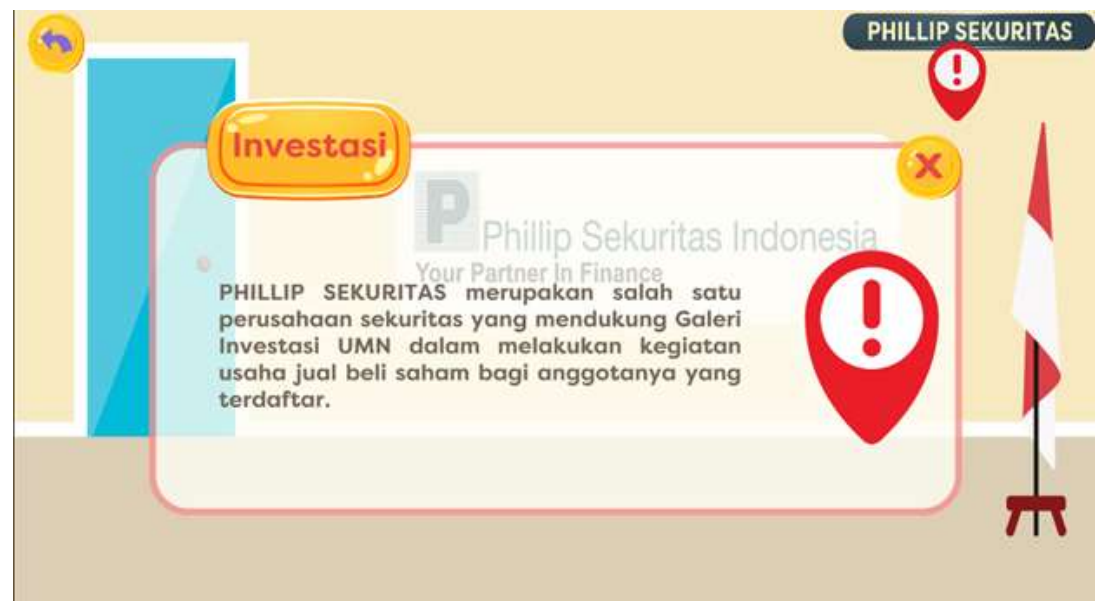

Figure 6: GASING Stage 1 Philip Sekuritas Indonesia

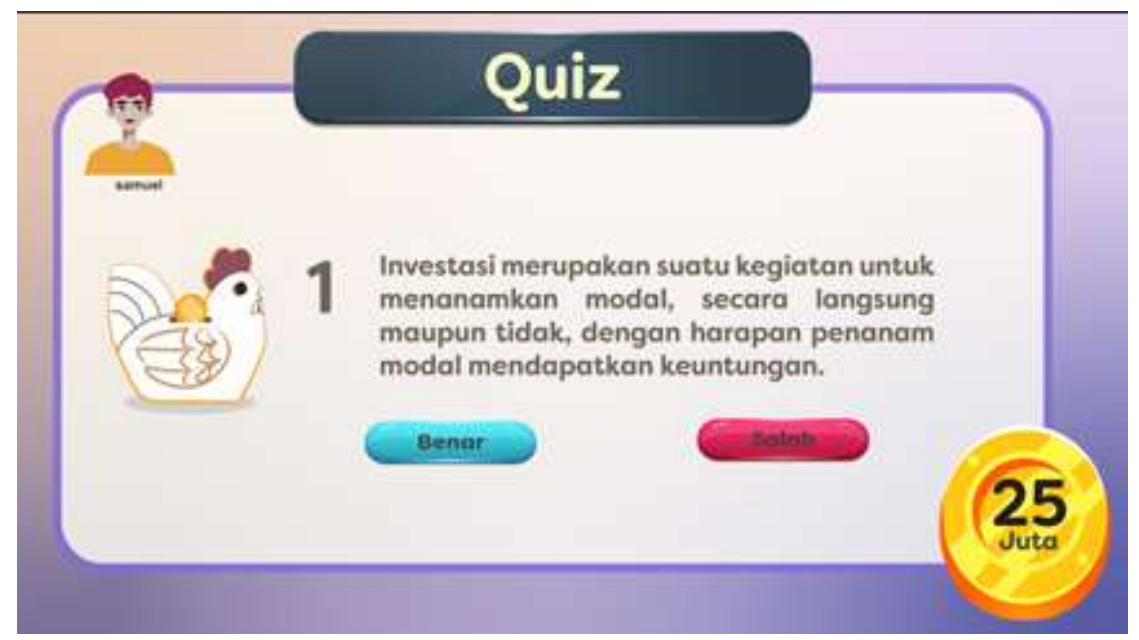

Figure 7: Quiz 1

Published by:

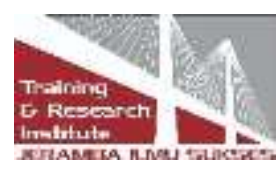




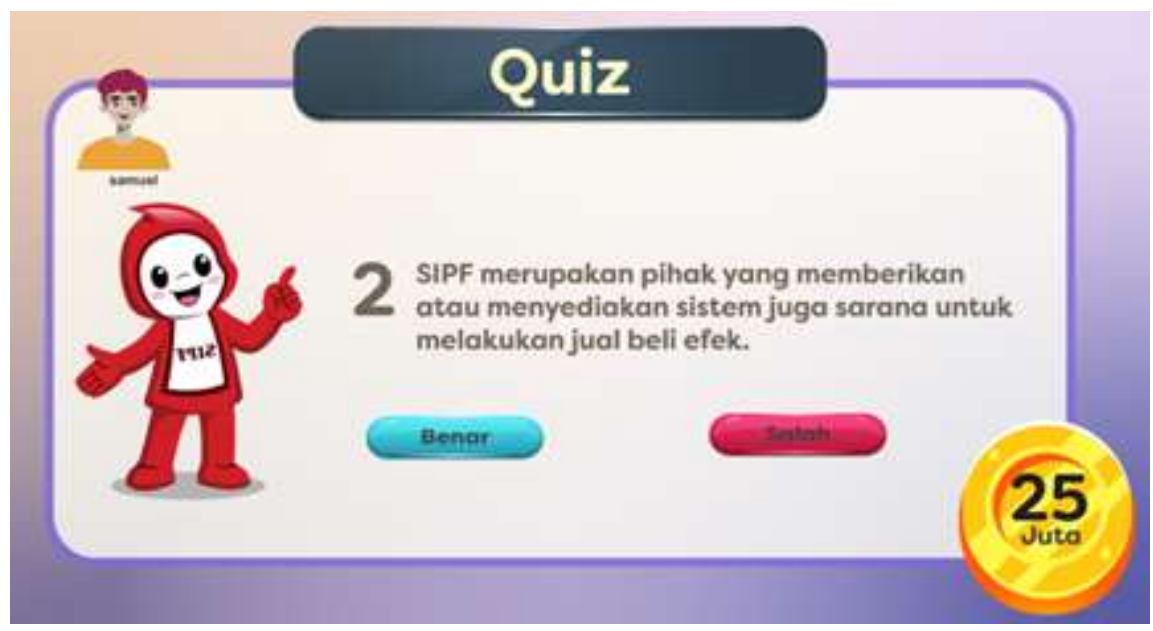

Figure 8: Quiz 2

\section{Level 2}

The player will learn the stock market mechanism in the second level and dive into the stock market simulation. Players can simulate buying and selling 18 types of stocks for 15 minutes. Stock price changes are made every 2 minutes. When the player gets a profit above $10 \%$ of the initial capital of 10 million rupiahs, the player plays to level next. If not, it will repeat at level 2.

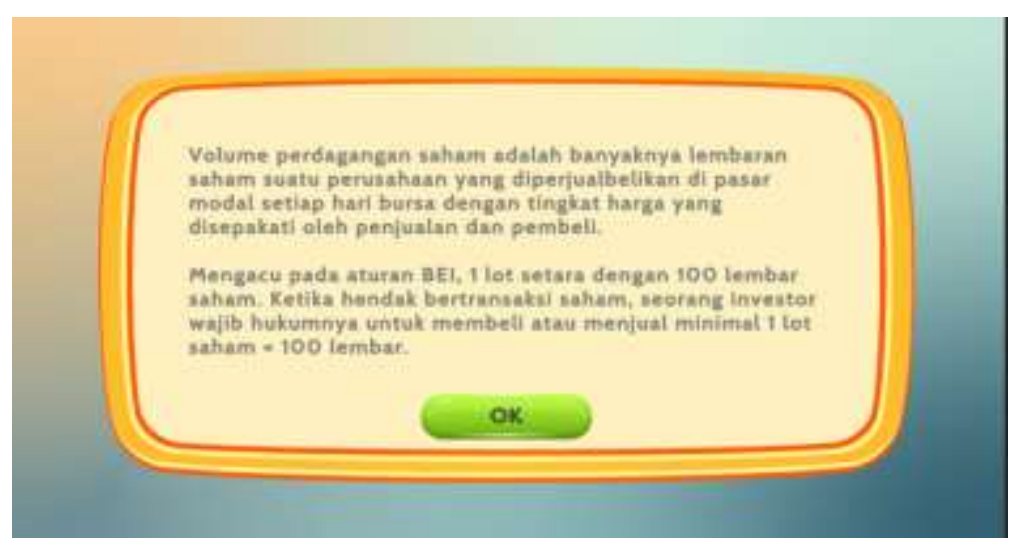

Figure 9: GASING Stage 2 


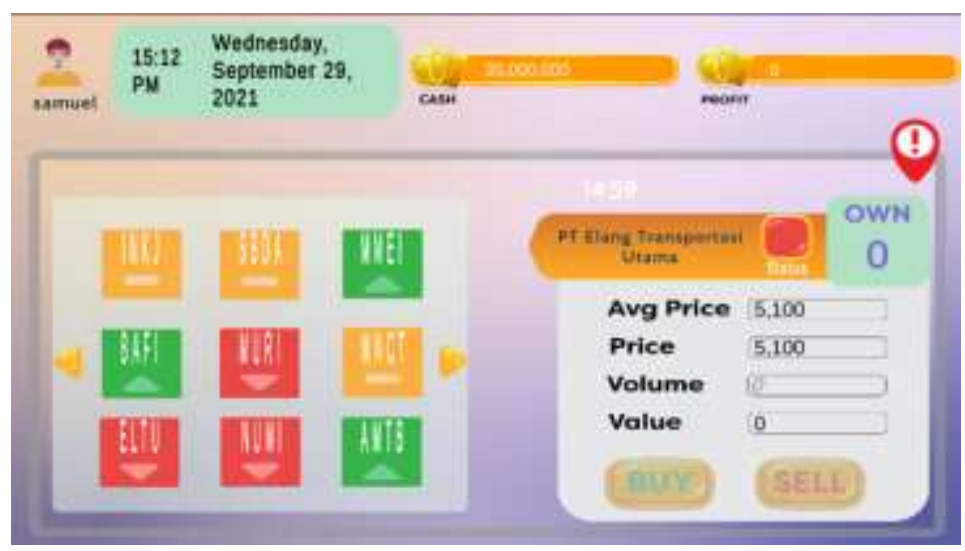

Figure 10: Stage 2 Stock Options

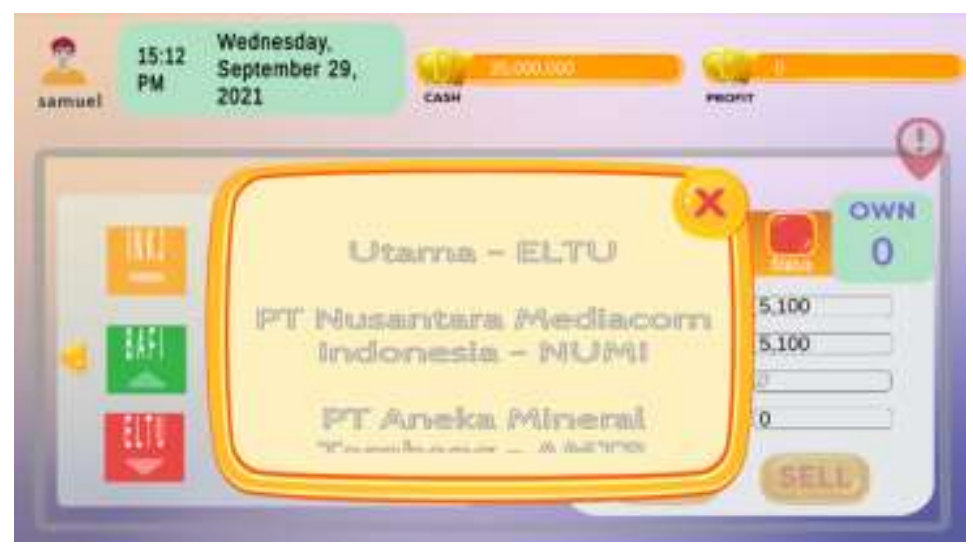

Figure 11: Stage 2 Stock Options Description

\section{Level 3}

In the third level, the player will simulate stock trade following the real market. The stock price displayed at this level is a real-time price based on the IDX-Indonesia Stock Exchange with several stock lists that can be chosen.



Figure 12: Loading Screen

Published by:

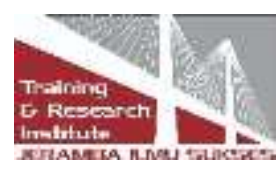




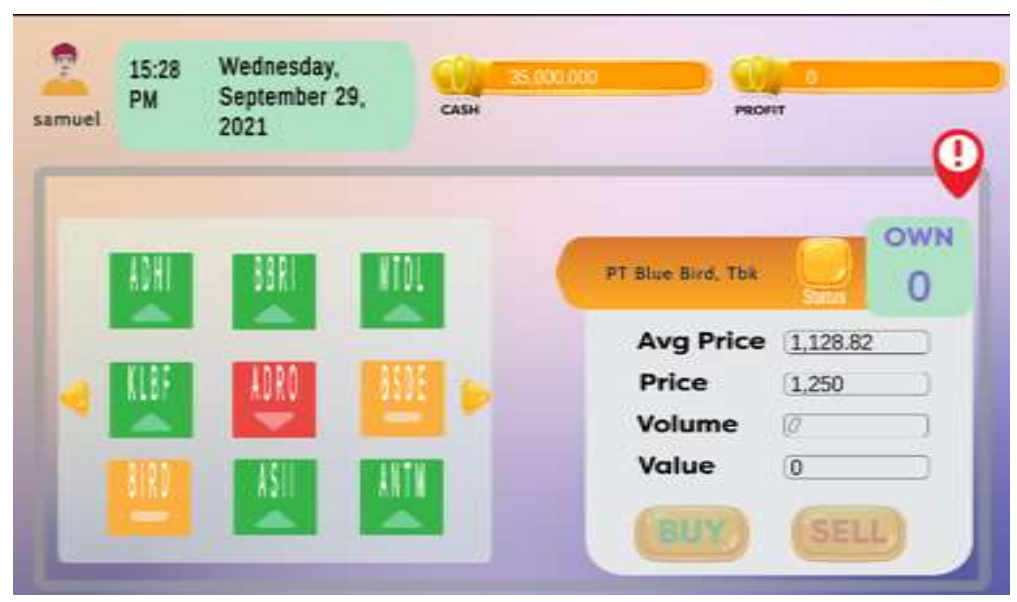

Figure 13: Stage 3 Stock Options

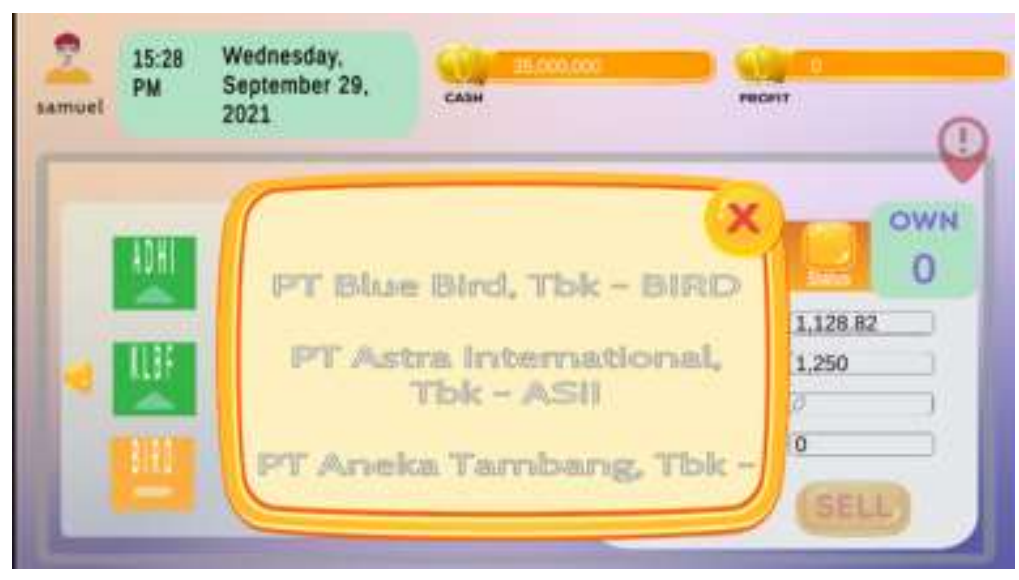

Figure 14: Stage 3 Stock Options Description

\section{Implementation of Gamification System Design: GASING}

A study conducted by Brown \& Russel (2019) found that gamification can increase the learning capabilities of the students (Azani et al., 2019). Therefore, the GASING gamification is also expected can fulfil educational purposes by having the following elements:

1. Points: to measure the success level of each high-school student gamer. Points element would also increase the enthusiasm to achieve the targeted level.

2. Levels/stages: to give sensation for game advancement among high-school student gamers.

3. Medal: as an appreciation for finishing the tasks.

4. Leaderboard: to keep the high-school student gamers motivation to increase their achievement.

5. Prizes: an effective way to motivate high-school student gamers.

6. Storyline: to assist high-school student gamers more interested with the game flow in order to finish the educational process.

Published by: 
Following is the stages in designing and releasing GASING using the Game Development Life Cycle (GDLC) method (Dicheva, 2015):

1. Initiation: by collecting data to set up the needs of the high-school student gamers as references. Initiation is an early stage in which observation, interview and surveying by distributing questionnaires was used to get the needs and requirements of the gamers.

2. Pre-production: a process in designing the GASING game application, starting from making GASING Game Design Document, then designing the system to run the application.

3. Production: started with the making and collecting GASING game asset and making program.

4. Testing: After the production process is finished, the testing process is conducted in an internal team using black-box testing.

5. Beta: after internal testing, GASING game application will be tested to beta testers.

6. Release: After the testing application showed that the game is running well, the GASING game is ready to introduce and published to high-school students as the primary target users.

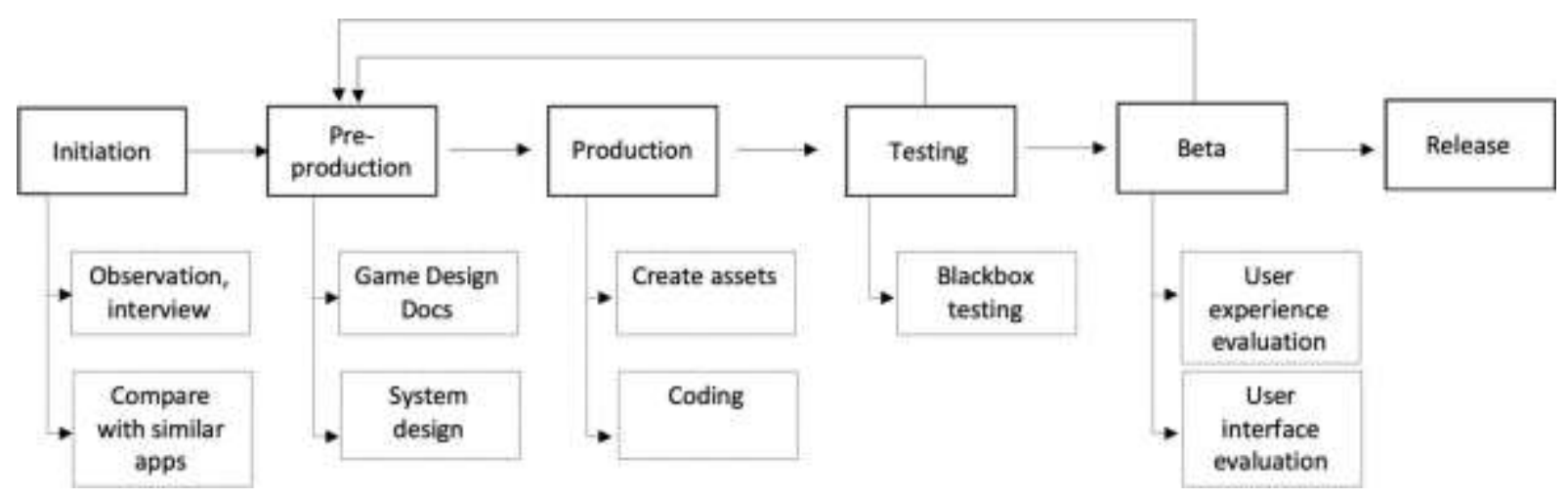

Figure 15. GASING Game Development Life Cycle

\section{Conclusion}

The research still has a limitation in the effective measurement of gamification in the education of the stock market since this gamification model is still new and released. In addition, the effects of gamification toward engagement and motivation in education so far need further study. Hence, to measure the effectiveness of gamification in the stock market, it might be suitable to use the download data from GASING from the Google Play Store to measure high school students' interest in investment. In addition, a further survey regarding the knowledge, engagement, and increase of SID can be an option to measure the effectiveness of gamification in the stock market. In conclusion, the effectiveness of gamification in stock market education needs more research. However, it is hoped to affect the stock market education positively.

Published by:

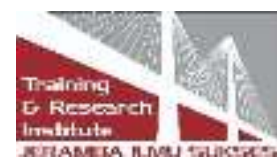




\section{Acknowledgements}

The author would like to thank Indonesia Stock Exchange and Indonesia SIPF for financial support to this study.

\section{References}

Alsawaier, R. S. (2018). The effect of gamification on motivation and engagement. The International Journal of Information and Learning Technology, 35(1), 56-79. https://doi.org/10.1108/ijilt-02-2017-0009

Antonaci, A., Klemke, R., Lataster, J., Kreijns, K., \& Specht, M. (2019). Gamification of MOOCs Adopting Social Presence and Sense of Community to Increase User's Engagement: An Experimental Study. Lecture Notes in Computer Science, 172-186. https://doi.org/10.1007/978-3-030-29736-7_13

Azani Cempaka Sari, Andre Mohammad Fadillah, Junaidy Jonathan, Mahendra Rezky David Prabowo (2019). Interactive Gamification Learning Media Application For Blind Children Using Android Smartphone in Indonesia. Procedia Computer Science. Vol. 157, p. 589- 595, ISSN 1877-0509, https://doi.org/10.1016/j.procs.2019.09.018.

Brown, MT and Russel, JK (2019). Medication adherence: WHO cares?. Mayo Clin Proc. Apr;86(4):268-70. DOI: 10.4065/mcp.2011.0123.

Cavalcante, R. C., Brasileiro, R. C., Souza, V. L., Nobrega, J. P., \& Oliveira, A. L. (2016). Computational Intelligence and Financial Markets: A Survey and Future Directions. Expert Systems with Applications, $55,194-211$. https://doi.org/10.1016/j.eswa.2016.02.006

D Dicheva, AG DD, AG. Gamification in Education: A Systematic Mapping Study (2015). Educational Technology \& Society. Vol III(18).

Ghanem, BHH.; Rosso, P.; Rangel, F. (2020). An Emotional Analysis of False Information in Social Media and News Articles. ACM Transactions on Internet Technology. 20(2):1-18. https://doi.org/10.1145/3381750

Kadoya, Y., \& Khan, M. S. R. (2020). Financial Literacy in Japan: New Evidence Using Financial Knowledge, Behavior, and Attitude. Sustainability, 12(9), 3683. https://doi.org/10.3390/su12093683

Kh, R. (2021, August 24). Jangan Tertipu! Investasi Bodong Mulai Pasang Logo \& Nama OJK. CNBC Indonesia. https://www.cnbcindonesia.com/investment/20210824164142-21270879/jangan-tertipu-investasi-bodong-mulai-pasang-logo-nama-ojk

KSEI. (2021). Statistik Pasar Modal Indonesia.

Matraeva, L.V., Vasiutina, E.S., Belyak, A.V., Solodukha, P.V., Bondarchuk, N., \& Efimova, M.R. (2019). Economic Model of Generation Z Behavior. Academic Journal of Interdisciplinary Studies.

Nano, D. (2015). The Interrelationship between Financial Attitude, Financial Behavior and Financial Knowledge. International Journal of Business \& Technology, 4(1).

Published by:

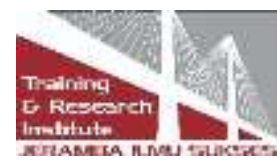




\section{https://doi.org/10.33107/ijbte.2015.4.1.09}

Natalia, M., Kurniasari F., Hendrawaty, E., \& Oktaviani, V. (2020). Pengaruh Literasi Keuangan Terhadap Inklusi Keuangan Dengan Menggunakan Social Capital Sebagai Variable Mediator. Ultima Management: Jurnal Ilmu Manajemen, 12(1), 16-33. https://doi.org/https://doi.org/10.31937/manajemen.v12i1.1522

Nurhadi, M. (2021, November 10). Dalam 10 Tahun, Komplotan Investasi Bodong Raup Untung Rp117 Triliun! https://www.suara.com/bisnis/2021/11/10/121908/dalam-10- tahun-komplotaninvestasi-bodong-raup-untung-rp117-triliun?page $=1$

Pahlevi, R. W., \& Oktaviani, I. I. (2018). Determinants of Individual Investor Behaviour in Stock Investment Decisions. AFRE (Accounting and Financial Review), 1(2). https://doi.org/10.26905/afr.v1i2.2427

Rai, K., Dua, S., \& Yadav, M. (2019). Association of Financial Attitude, Financial Behaviour and Financial Knowledge Towards Financial Literacy: A Structural Equation Modeling Approach. FIIB Business Review, 8(1), 51-60. https://doi.org/10.1177/2319714519826651

Ramadhani, N. (2021, October 11). Mengenal Slogan "Yuk Nabung Saham" dan Cara Memulainya! Akseleran Blog. https://www.akseleran.co.id/blog/yuk-nabung-saham/

Soenarso, S. A. (2021, November 9). Kerugian akibat investasi bodong mencapai Rp 117 triliun dalam 10 tahun terakhir. kontan.co.id. $\quad$ https://investasi.kontan.co.id/news/kerugianakibat- investasi-bodong-mencapai-rp-117-triliun-dalam-10-tahun-terakhir

Survei Nasional Literasi dan Inklusi Keuangan 2019. (2020). Otoritas Jasa Keuangan. https://www.ojk.go.id/id/berita-dan-kegiatan/publikasi/Pages/Survei-Nasional-Literasidan-Inklusi-Keuangan-2019.aspx

van Roy, R., \& Zaman, B. (2018). Need-supporting gamification in education: An assessment of motivational effects over time. Computers \& Education, 127, 283-297. https://doi.org/10.1016/j.compedu.2018.08.018

Yanto, Kurniasari, F Kristianus (2020). Determinant Factors Influencing Stock Investment Behavior for Millenial in Adopting Investment Management Application Using Technology Acceptance Model (TAM) Approach. Proceeding, $6^{\text {th }}$ Indonesian Finance Association Proceeding, pp.94-108.

\section{Copyrights}

Copyright for this article is retained by the author(s), with first publication rights granted to the journal.

This is an open-access article distributed under the terms and conditions of the Creative Commons Attribution license (http://creativecommons.org/licenses/by/4.0/)

Published by: 